\title{
The Relationship between Happiness and Self-Awareness among Introverts and Extroverts
}

\author{
Mandana Bagherian, Adis Kraskian Mojembari, Parviz Naghibian, Sanam Farshad Nik \\ Islamic Azad University, Tehran, Iran \\ Email: satyba@gmail.com
}

Received 28 May 2016; accepted 12 July 2016; published 15 July 2016

Copyright (C) 2016 by authors and Scientific Research Publishing Inc.

This work is licensed under the Creative Commons Attribution International License (CC BY). http://creativecommons.org/licenses/by/4.0/

(c) (i) Open Access

\begin{abstract}
It is commonly believed that extroverts are happy and felicitous, and introversion is usually regarded as the state of having no fun or happiness in life. The present research is intended to investigate the relationship between extroversion (one of the Big Five Personality Traits) and happiness level among individuals to figure out whether there is any significant relationship between extroversion/introversion and happiness. Also the level of self-awareness of the extroverts and introverts is measured. In this study the NEO Five-Factor Inventory (NEO-FFI), which comprises 60 items (12 items per domain), and MUNSH Scale of Happiness as well as McGraw-Hill's Self Awareness Questionnaire were used. The participants were 150 students ranging from 18 to 50 years. The regression analysis was used to figure out the relationship between variables. The findings suggest that extroverts are happier than introverts $(p<.01)$ and the level of self-awareness is higher in extroverts in comparison with the introverts $(p<.01)$.
\end{abstract}

\section{Keywords}

Big Five Personality Traits, Extroversion, Self-Awareness, Introversion, Students

\section{Introduction}

Perhaps, one of the most important challenges in today's life is happiness, and one of the most significant factors in determining the true meaning of life is happiness. Happiness is so significant that it can reduce the mortality rate among humans and increase life expectancy among individuals (Beatle et al., 2015). Happiness has been undoubtedly one of the most dreams of mankind and all do their best to achieve it. The level of happiness depends on the individual's assessment of their self and lives. These assessments can be cognitive such as the 
judgements made concerning satisfaction or they can be emotional which are revealed in reaction to the events in life (Blanchflower \& Oswald, 2004). The happy people have a more positive idea towards life and events. They have a higher level of satisfaction towards family, occupation, education and other aspects of life (Eysenk, 1996).

\section{Literature Review}

\subsection{Personality}

Personality refers to a set of mental characteristics used to classify people. These characteristics can have stable effects on human behavior. Personality comprises the attributes, tendencies, or traits which result in stability in human behavior. In fact, personality consists of the characteristics and attributes which result in human behavioral differences, stability of behavior over time and behavior permanence in different situations. These characteristics can be personal and common among different groups, but their patterns are uniquely personal in different people (Feist \& Feist, 2011). Those who are neurotic tend to experience anxiety, insecurity, low level self-esteem, shame, and aggression (McCrae \& Costa, 1987). In contrast, those with lower levels of neuroticism have less negative emotional characteristics. They are less anxious, less depressed, and less amenable to stress. On the other end are the people who are more pessimistic, dubious, unemotional, manipulative, unkind, uncooperative, unstable, obstinate and aggressive. In addition, people with the higher sense of responsibility are more organized, dependable, and ambitious with more energy and stronger wills (Koob, 2007/2015). A closer look at an individual can provide us with a comprehensive and precise look concerning the inter-individual, experiential, attitudinal and motivational emotional states, and personality traits can analyze the attributes more precisely (McCrae \& Costa, 1992). Based on the five personality trait model, personality can be better understood in the light of Neuroticism, Extroversion, Agreeableness, Conscientiousness, and Openness (McAdams \& Pals, 2006). Neuroticism refers to a continuum of emotional instability to emotional stability (McAdams \& Pals, 2006; Mahoney \& Stacon, 2005; Rice, 2007). According to John and Srivastava (1999), Extroversion is an energetic approach to the material and social life which consists of socialization, activity, decisiveness and courage. The introverts, in contrast with the extroverts, are reported to experience less enjoyment and more pain in face to face personal meetings (Ward \& Tracey, 2004). People who are open to experience are amenable to new ideas and unusual values and experience positive and negative emotions more deeply and intensely than the inflexible people. These people show agreeableness (McCrae \& Costa, 1987). People who are less open to experience are more conventional, strict. They are less creative, imaginative and analytic and have lower tendency towards interest (Koob, 2007/2015). Conscientiousness reflects responsibility; that is, being exact, responsible, and organized with plans (Rice, 2007/2015).

\subsection{Happiness}

In a study conducted by Beatie et al. among millions of men and women over 60 in England, they observed that happiness can drastically reduce anxiety, promote their health and reduce the risk of death up to 10 years. Another study in Japan showed that happiness can significantly reduce the risk of death among men with age ranges between 40 to 69 suffering from heart problems (Shirai, Iso, \& Ohira, 2009). A number of studies have also shown the significant effect of happiness on educational improvement and motivation (Ghasemi et al., 2011; Hassanzadeh \& Mahdinejad, 2013; Tabbodi et al., 2015). Other investigations also the positive relationship between happiness on the one hand and self-compassion and mindfulness on the other (Hollis-Walker \& Colosimo, 2011). All these studies underscore the effectiveness of happiness in life. Some studies show that the extroverts are happier than introverts (DeNeve \& Cooper, 1998; Diener \& Lucas, 1999, 2000; Lucas \& Fujita, 2000). Happiness and extroversion are so intertwined that a number of researchers regard extroversion as one of the important factors of happiness (Lucas, Diener, Groob, Sue, \& Shaw, 2000; Telegen, 1985; Watson \& Clark, 1997). Other researchers believe that the there are other determining factors in this regard. For instance, it is believed that ARH (Affective Reactivity Hypothesis) can also account for happiness and enjoyment (Larsen \& Ketelaar, 1991; Sterlow, 1987; Tegen, cited in Orelemans, 1985; Baker, 2014). Khosroshahi et al. (2013) have reported a positive correlation between happiness and extroversion. Happiness is one of the most important concepts and components in human life and a number of fields and sub-fields in Psychology attempt to define it with the intention of making it easier for people to achieve. Happiness comprises three significant components: Positive 
Emotions, Life satisfaction and Absence of negative emotions, such as depression and anxiety. Argyle et al. (1990) and Myers and Diener (1995) also believe that happiness has emotional, social, and cognitive components. Social components will result in the improvement of social relationship and social support. The cognitive component results in some personal and idiosyncratic thoughts and interpretation of the information, and interpret the daily events to make him more optimistic. Positive relationship with others, goal-directed life, personal development, love of nature and mankind are also considered to be the components of happiness. Positive emotions such as happiness prepare the organism for future challenges (Kar, 2004; Erkison, 2000). They believe that those who experience the positive motivation can make use of time in their interest; therefore, they are away from unpredictable dangers and indefinite failures which give them the chance to follow their goals.

\subsection{Method}

The present study enjoys a non-experimental, and correlational design based on regression analysis. The participants were 430 students (280 female and 150 male) ranging from 18 to 50 years selected from among the students studying in Alborz Province Universities. The convenient sampling was utilized and 150 participants were selected based on the extroversion scores considering the mean and standard deviations.

\section{Instruments}

\subsection{Neo Five-Factor Inventory}

The Neo Five-factor Inventory was used to measure the five BIG personality traits (Costa \& McCrea, 1992) which consists of 60 questions and the five personality traits (Openness to Experience, Extroversion, Conscientiousness, Agreeableness and Neuroticism) are each tested by 12 questions. This inventory is based on the five degree Likert scale. The reliability index of this inventory was from .75 to .83. The internal consistency index, as reported in Garoosi, Farshi, Mahyar and Ghazi Tabtabyee (2001, quoted in Hosseini et al., 2014) were .86, .73, .56, .68, .87 for Neuroticism, Extroversion, Openness to Experience, Agreeableness and Conscientiousness respectively. The Cronbach Alpha Index of the inventory was .765.

\subsection{Memorial University of Newfoundland Scale of Happiness}

Memorial University of Newfoundland Scale of Happiness has been designed to measure happiness. Kozma and Stones (2000) designed a test which emphasizes the amount and intensity of positive and negative affects. Each of these affects has two long range and short range aspects. The short range items illustrate state affects while the long range items are related to the positive and negative affects. Each state affect consists of five questions and each positive/negative affect consists of 7 questions which totally comprise 24 questions. The validity index of MUNSH is reported to be from .70 to .85 in different studies (Kosma et al., 2000). In addition the correlation of this scale with the other scales of mental health such as GAS Happiness Scale (.50) indicates the convergent validity of this scale (Maki, 2005; Wals, 2006). In Iran in a research study by Babapoor et al., the internal consistency of this scale was reported to be .71 . Also, the same study approved the construct validity of the same scale. In a research by Alipoor et al., the Cronbach Alpha reported for the reliability of this scale was reported to be .76. In this scale the positive short range and long range affects are first put together and then subtracted from the negative short range and long range affects. The highest possible score is 24 . The higher the score, the better the emotional status of the individual. The Cronbach Alpha of the scale calculated in the present study is .725.

\subsection{McGraw-Hill Self Awareness Questionnaire}

This questionnaire was has been designed to discover the individual's understanding of his own self and how to improve his own special needs, and it was revised by McGraw-Hill in 2002. The participants' replies to the items should reflect the tendencies and behaviors they actually have rather than the ones they love to have. This questionnaire is a seven option Likert scale. The Cronbach Alpha calculated in the present study is .972.

\section{Procedure}

The present research considers questionnaires distributed among available student-samples. All instructions were presented carefully to each participant. The researcher examined all the questioners to be answered per- 
fectly by the participants in order to avoid missing a single question unanswered. Among 430 collected questioners, 150 samples (75 extroverted, 75 introverted) were selected and analysed.

\section{Results}

Before testing the hypotheses and answering the research questions four points have to be taken into account:

1) To ensure that there is a significant difference in two selected groups in regard to extroversion obtained from the NEO scale, the two independent groups were compared with each other and Table 1 shows the results obtained:

The results of the test show that there is a significant difference between the two groups in regard to extroversion.

2) Homogeneity of the two groups with regard to demographic variables:

Chi-square was used to compare the frequency distribution of sex, education, marital status in the two groups and the mean test was used to determine the age in the two independent groups. The results of these tests are shown in Table 2.

The results indicate that the two groups are homogeneous with regard to demographic characteristics.

3) Normality of the Distribution of Research variables:

The results of the Kolmogorov Smirnov test is reported to show the normal distribution of the research variables (Table 3).

Based on the results, the distribution of both variables is normal, therefore the parametric tests can be used to test the research hypotheses (Table 4).

Research Hypothesis 1: Extroverts are happier than extroverts.

Table 1. Extroversion scores for two groups $(\mathrm{N}=150)$.

\begin{tabular}{|c|c|c|c|c|c|c|c|c|}
\hline \multirow{2}{*}{ Group } & \multirow{2}{*}{$\underline{\mathrm{n}}$} & \multirow{2}{*}{$\underline{\mathrm{M}}$} & \multirow{2}{*}{$\underline{\mathrm{SD}}$} & Levene's test for & \multicolumn{4}{|c|}{ t-test for equality of means } \\
\hline & & & & $\underline{\mathrm{F}}$ & Mean difference & Std. error difference & $d f$ & $\underline{\mathrm{t}}$ \\
\hline Extraverted & 75 & 49.40 & 2.52 & \multirow{2}{*}{2.010} & \multirow{2}{*}{18.99} & \multirow{2}{*}{.450} & \multirow{2}{*}{148} & \multirow{2}{*}{$42.187^{* *}$} \\
\hline Introverted & 75 & 30.41 & 2.97 & & & & & \\
\hline
\end{tabular}

Table 2. (a) Comparison of homogeneity of two groups with regard to sex, education and marital status $(\mathrm{N}=150)$; (b) Comparison of homogeneity of the two groups with regard to age $(\mathrm{N}=150)$.

(a)

\begin{tabular}{|c|c|c|c|c|c|c|c|c|c|c|c|}
\hline & & \multicolumn{3}{|c|}{ Extraverted $(\mathrm{n}=75)$} & \multicolumn{3}{|c|}{ Introverted $(\mathrm{n}=75)$} & \multicolumn{2}{|c|}{ Total $(\mathrm{n}=150)$} & \multicolumn{2}{|c|}{ Equality Tes } \\
\hline & & $\underline{f}$ & $\%$ of group & $\%$ of total & $\underline{F}$ & $\%$ of group & $\%$ of total & $\underline{\mathrm{f}}$ & $\%$ & $\chi^{2}$ & Sig. \\
\hline \multirow{2}{*}{ Sex } & Male & 29 & 50.0 & 19.3 & 29 & 50.0 & 19.3 & 58 & 38.7 & \multirow{2}{*}{.000} & \multirow{2}{*}{ N.S. } \\
\hline & Female & 46 & 50.0 & 30.7 & 46 & 50.0 & 30.7 & 92 & 61.3 & & \\
\hline \multirow{3}{*}{ Education } & Bachelor students & 56 & 47.5 & 37.3 & 62 & 52.5 & 41.3 & 118 & 78.7 & \multirow{3}{*}{2.112} & \multirow{3}{*}{ N.S. } \\
\hline & Master students & 18 & 58.1 & 12.0 & 13 & 41.9 & 8.7 & 31 & 20.7 & & \\
\hline & PhD students & 1 & 100.0 & .7 & 0 & .0 & .0 & 1 & .7 & & \\
\hline \multirow{2}{*}{ Marital Status } & Single & 54 & 46.2 & 36.0 & 63 & 53.8 & 42.0 & 117 & 78.0 & \multirow{2}{*}{3.147} & \multirow{2}{*}{ N.S } \\
\hline & Married & 21 & 63.6 & 14.0 & 12 & 36.4 & 8.0 & 33 & 22.0 & & \\
\hline
\end{tabular}

(b)

\begin{tabular}{|c|c|c|c|c|c|c|c|c|c|}
\hline \multirow{2}{*}{ Group } & \multirow{2}{*}{$\underline{\mathrm{n}}$} & \multirow{2}{*}{$\underline{\mathrm{M}}$} & \multirow{2}{*}{$\underline{\mathrm{SD}}$} & \multirow{2}{*}{$\begin{array}{c}\text { Levene's test for equality of variances } \\
\text { F }\end{array}$} & \multicolumn{4}{|c|}{ t-test for equality of means } & \multirow{2}{*}{ Sig. } \\
\hline & & & & & Mean difference & Std. error difference & $d f$ & $\underline{\mathrm{t}}$ & \\
\hline Introverted & 75 & 26.33 & 7.23 & 3.860 & 1.32 & 1.141 & 148 & 1.157 & N.S. \\
\hline
\end{tabular}


Table 3. Results of Kolmogorov Smirnov test.

\begin{tabular}{|c|c|c|c|c|c|c|c|c|c|c|}
\hline \multirow{2}{*}{$\underline{\text { Group }}$} & \multirow{2}{*}{ Variable } & \multirow{2}{*}{$\underline{\mathrm{n}}$} & \multirow{2}{*}{$\underline{\mathrm{M}}$} & \multirow{2}{*}{$\underline{\mathrm{SD}}$} & \multicolumn{3}{|c|}{ Most extreme differences } & \multirow{2}{*}{ Kolmogorov-Smirnov Z } & \multirow{2}{*}{\multicolumn{2}{|c|}{ Sig. }} \\
\hline & & & & & Absolute & Positive & Negative & & & \\
\hline \multirow{2}{*}{ Extraverted } & Happiness & 75 & 9.39 & 7.98 & .135 & .070 & -.135 & 1.169 & .130 & N.S. \\
\hline & Self-awareness & 75 & 54.31 & 11.48 & .137 & .072 & -.137 & 1.190 & .118 & N.S. \\
\hline \multirow[t]{2}{*}{ Introverted } & Happiness & 75 & -5.04 & 9.46 & 102 & .102 & -.076 & .885 & .413 & N.S. \\
\hline & Self-awareness & 75 & 48.53 & 10.89 & .078 & .054 & -.078 & .676 & .751 & N.S. \\
\hline
\end{tabular}

Table 4. Comparison of happiness among extroverts and introverts.

\begin{tabular}{|c|c|c|c|c|c|c|c|c|c|}
\hline \multirow{2}{*}{ Group } & \multirow{2}{*}{$\underline{\mathrm{n}}$} & \multirow{2}{*}{$\underline{\mathrm{M}}$} & \multirow{2}{*}{$\underline{\mathrm{SD}}$} & \multirow{2}{*}{$\begin{array}{c}\text { Levene’s test for } \\
\text { equality of variances } \\
\text { F }\end{array}$} & \multicolumn{4}{|c|}{ t-test for equality of means } & \multirow{2}{*}{$\begin{array}{c}\text { Effect size } \\
\eta^{2}\end{array}$} \\
\hline & & & & & Mean difference & Std. error difference & $d f$ & $\underline{\mathrm{t}}$ & \\
\hline Extraverted & 75 & 9.39 & 7.98 & \multirow[b]{2}{*}{$3.953^{*}$} & \multirow[b]{2}{*}{14.43} & \multirow[b]{2}{*}{1.429} & \multirow[b]{2}{*}{143.93} & \multirow[b]{2}{*}{$10.093^{* *}$} & \multirow[b]{2}{*}{.408} \\
\hline Introverted & 75 & -5.04 & 9.46 & & & & & & \\
\hline
\end{tabular}

Table 5. Comparison of self-awareness among extroverts and introverts.

\begin{tabular}{|c|c|c|c|c|c|c|c|c|c|}
\hline \multirow{2}{*}{$\underline{\text { Group }}$} & \multirow{2}{*}{$\underline{\mathrm{n}}$} & \multirow{2}{*}{$\underline{\mathrm{M}}$} & \multirow{2}{*}{$\underline{\mathrm{SD}}$} & \multirow{2}{*}{$\begin{array}{c}\text { Levene's test for } \\
\text { equality of variances } \\
\text { F }\end{array}$} & \multicolumn{4}{|c|}{ t-test for equality of means } & \multirow{2}{*}{$\begin{array}{c}\text { Effect } \\
\text { size } \\
\eta^{2}\end{array}$} \\
\hline & & & & & Mean difference & Std. error difference & $d f$ & $\underline{t}$ & \\
\hline Extraverted & 75 & 54.31 & 11.48 & \multirow[b]{2}{*}{.050} & \multirow[b]{2}{*}{1.827} & \multirow[b]{2}{*}{5.77} & \multirow[b]{2}{*}{148} & \multirow[b]{2}{*}{$3.160^{* *}$} & \multirow[b]{2}{*}{.063} \\
\hline Introverted & 75 & 48.53 & 10.89 & & & & & & \\
\hline
\end{tabular}

${ }^{* *} p<.0$.

Statistical Conclusion: As the t observed (10.093) is larger than t critical with the degree of freedom of 143.93 in a one tail test (2.357), the null hypothesis which states that there is no difference between the means of two groups is rejected by 99\%. In other words, the mean score of the extroverts (9.39) is on a higher level than that of introverts $(-5.04)$. With respect to the index calculated almost $44 \%$ of the happiness variable is determined by extroversion.

Result: Extroverts are happier than introverts.

Research Hypothesis 2: Extroverts have a higher level of self-awareness than introverts (Table 5).

Result: As the t observed (3.160) is larger than t critical with the degree of freedom of 148 in a one tail test (2.357), the null hypothesis which states that there is no difference between the means of two groups is rejected by $99 \%$. In other words, the mean score of the extroverts' self-awareness (54.31) is on a higher level than that of introverts (48.53). Almost 6\% of the self-awareness variable id determined by introversion.

Result: Extroverts have a higher level of self-awareness than introverts.

\section{Discussion}

The purpose of the present study was to find a meaningful relationship happiness and extroversion, and figure out whether extroverts are happier than introverts. The statistical results prove this point. This study is line with the previous research which states that extroverts have a higher level of happiness in their lives than introverts. Similar studies which have focused on self-awareness have come to the conclusion that extroversion has a meaningful relationship with self-awareness. In a research on 1364 participants who performed 13937 tasks, Oerlemans and Bakker (2014) found out that the level of happiness of the extroverts on tasks with external reinforcement (Rewards) was higher than that of the introverts. Of course these results are only valid in tasks with external reinforcement. In a study on 200 participants, Khosroshahi et al. (2012) found out that there is a direct meaningful relationship between happiness, and other personality traits such as extroversion, openness to experience, 
agreeableness and conscientiousness $(p<.01)$ while the same study showed a negative meaningful relationship between happiness and neuroticism $(p<.01)$. In a similar study on 96 females and 27 males who were mentally healthy, Hollis-Walker and Colosimo (2010) found a meaningful direct relationship between extroversion, happiness, mindfulness, and self-compassion. De Young, Peterson, and Higgins (2002) in a study on 245 university students and 222 individuals found out that extroversion and openness to experience are regarded as the subcomponents of flexibility which include all the characteristics of compatibility and flexibility.

\section{Limitations}

The first element leads to a limitation of the present study is the type of sampling, which is available sampling. The fact that participants are confined to the available ones, confirms that the conclusion may suffer from some deviations once a change occurs in sample selection. The second element, which intensifies the first one, is that the participants are among university students of higher education, which admits the restriction of conclusion to the exact group of participants, not others. These factors may affect findings generalization and limit its reliability due to considering of students.

\section{Directions for the Future}

This research is capable of scrutinizing all types of samples in different societies to investigate the relationship between extroversion/introversion and happiness. In addition, other personality traits can be examined for future directions.

\section{Conflict of Interest}

There is no conflict of interest.

\section{Participants}

In this study, Participants involved human beings and consisted of university students.

\section{Consent}

There is a completely consent between authors to result this findings and publish this manuscript.

\section{References}

Argyle, M., \& Lu, L. (1990). Happiness and Social Skills. Journal of Personality and Individual Differences, 11, $1255-1261$. http://dx.doi.org/10.1016/0191-8869(90)90152-H

Blanchflower, D. G., \& Oswald, A. J. (2004). Money, Sex and Happiness: An Empirical Study. The Scandinavian Journal of Economics, 106, 393-415. http://dx.doi.org/10.1111/j.0347-0520.2004.00369.x

Costa, P. T., \& McCrea, R. R. (1992). Domains and Facets: Hierarchial Personality Assessment Using the Revised NEO Personality Inventory. Journal of Personality Assessment, 64, 21-50. http://dx.doi.org/10.1207/s15327752jpa6401_2

DeNeve, K. M., \& Cooper, H. (1998). The Happy Personality: A Meta-Analysis of 137 Personality Traits and Subjective Well-Being. Psychological Bulletin, 124, 197-229. http://dx.doi.org/10.1037/0033-2909.124.2.197

Diener, E., \& Lucas, R. E. (1999). Personality and Subjective Well-Being. In D. Kahneman, E. Diener, \& N. Schwarz (Eds.), Well-Being: The Foundations of Hedonic Psychology (pp. 213-229). New York: Russell Sage Foundation.

Diener, E., \& Lucas, R. E. (2000). Subjective Emotional Well-Being, Hand Book of Emotion. New York: Gulford University Press.

Eysenk, M. W. (1996). Happiness Psychology (Translated by K. Beygi \& M. Firoozbakht). Badr Publishing.

Feist, J., \& Feist, G. J. (2011). Theories of Personality (Translated by Y. S. Mohammadi). Ravan Publishing.

Ghasemi, F., Rastegar, A., Ghorban, J. R., \& Roozegar, M. R. (2011). The Relationship between Creativity and Achievement Motivation with High School Students’ Entrepreneurship. Procedia-Social and Behavioral Sciences, 30, 1291-1296. http://dx.doi.org/10.1016/j.sbspro.2011.10.250

Hassanzadeh, R., \& Mahdinejad, G. (2013). Relationship between Happiness and Achievement Motivation: A Case of University students. Journal of Elementary Education, 23, 53-65.

Hollis-Walker, L., \& Colosimo, K. (2011). Mindfulness, Self-Compassion, and Happiness in Non-Meditators: A Theoretical 
and Empirical Examination. Personality and Individual Differences, 50, 222-227. http://dx.doi.org/10.1016/i.paid.2010.09.033

Hosseini, S., Mojembari, A. K., \& Ferdosipour, A. (2014) The Contribution of Five Major Factors of Personality in Prediction of Ambiguity Tolerance. Thought \& Behavior in Clinical Psychology, 19, 17-26.

Khosroshahi, J. B., Hashemi Nosrat Abad, T., \& Mashinchi Abassi, N. (2013). The Relationship between Personality Traits, Emotional Intelligence and Happiness among University Students. Journal of Kermanshah University of Medical Science, 16.

Kozma, A., Stones, S., \& Stones, M. J. (2000). Stability in Components and Predictors of Subjective Well Being (SWB): Implications for SWB Structure. In E. Diener \& D. R. Rahtz (Eds.), Advances in Quality of Life Theory and Research (pp. 13-30). http://dx.doi.org/10.1007/978-94-011-4291-5_2

Larsen, R. J., \& Ketelaar, T. (1991). Personality and Susceptibility to Positive and Negative Emotional States. Journal of Personality and Social Psychology, 61, 132-140. http://dx.doi.org/10.1037/0022-3514.61.1.132

Lucas, R. E., Diener, E., Grob, A., Suh, E. M., \& Shao, L. (2000). Cross-Cultural Evidence for the Fundamental Features of Extraversion. Journal of Personality and Social Psychology, 79, 452-468. http://dx.doi.org/10.1037/0022-3514.79.3.452

Lucas, R. E., \& Fujita, F. (2000). Factors Influencing the Relation between Extraversion and Pleasant Affect. Journal of Personality and Social Psychology, 79, 1039-1056. http://dx.doi.org/10.1037/0022-3514.79.6.1039

Maki, A. A. (2005). The Relationship between Spirituality and Successful Aging Older Minority Women. Dissertation Abstracts International of Florida State University.

McAdams, D. P., \& Pals, J. L. (2006). A New Big Five: Fundamental Principles for an Integrative Science of Personality. American Psychologists, 3, 204-217. http://dx.doi.org/10.1037/0003-066X.61.3.204

McCrae, R. R., \& Costa, P. T. (1987). Validation of the Five Factor Model of Personality across Instruments and Observation. Journal of Personality and Social Psychology, 52, 81-90. http://dx.doi.org/10.1037/0022-3514.52.1.81

Myers, D. G., \& Diener, E. (1995). Who Is Happy? Psychological Science, 6, 10-19. http://dx.doi.org/10.1111/j.1467-9280.1995.tb00298.x

Oerlemans, W. G. M., \& Bakker, A. B. (2014). Why Extraverts Are Happier: A Day Reconstruction Study. Journal of Research in Personality, 50, 11-22. http://dx.doi.org/10.1016/j.jrp.2014.02.001

Shirai, K., Iso, H., Ohira, T. et al. (2009) Perceived Level of Life Enjoyment and Risks of Cardiovascular Disease in Incidence and Mortality: The Japan Public Health Center-Based Study. Circulation, 20, 956-963. http://dx.doi.org/10.1161/CIRCULATIONAHA.108.834176

Tabbodi, M., Rahgozar, H., \& Mozaffari Makki Abadi, M. (2015). The Relationship between Happiness and Academic Achievements. European Online Journal of Natural and Social Science, 4, 241-246.

Ward, C. C., \& Tracey, T. J. G. (2004). Relation of Shyness with Aspects of Online Relationship Involvement. Journal of Social and Personal Relationship, 21, 611-623. http://dx.doi.org/10.1177/0265407504045890

\section{Submit or recommend next manuscript to SCIRP and we will provide best service for you:}

Accepting pre-submission inquiries through Email, Facebook, Linkedin, Twitter, etc

A wide selection of journals (inclusive of 9 subjects, more than 200 journals)

Providing a 24-hour high-quality service

User-friendly online submission system

Fair and swift peer-review system

Efficient typesetting and proofreading procedure

Display of the result of downloads and visits, as well as the number of cited articles

Maximum dissemination of your research work

Submit your manuscript at: http://papersubmission.scirp.org/ 